\title{
Effect of Corporate Social Responsibility (CSR) and Compensation For Performance Management Manufacturing Companies Listed in Indonesia Stock Exchange Year 2014-2018
}

\author{
Yosafat Gea $^{1^{*}}$ and Haryetti ${ }^{2}$ \\ 1, 2 Universitas Riau, Pekanbaru, Indonesia
}

\begin{abstract}
In the midst of an increasingly modern business, requires companies to compete in maintaining their business and increase profits. Companies are also required not only for profit, but also improve the lives of the people, workers, stakeholders and gain confidence in the public eye. To achieve these objectives the company must pay attention to the company's performance and the factors that support the continuity of the company's performance. Corporate social responsibility and compensation management is an important aspect that should be viewed by the company to the sustainability of future performance. With the background of the problem, this study aims to examine the influence of corporate social responsibility and management compensation to company performance. The population in this study are all manufacturing companies listed in Indonesia Stock Exchange 2014-2018 period as many as 153 companies with a total sample of 21 companies were selected based on criteria predetermined. The analytical method used in this research is multiple linear regression and the results show that corporate social responsibility is a significant positive effect on company performance and compensation management is not significant positive effect on company performance. The more disclosures made by the company in the annual report the company's performance is increasing.
\end{abstract}

Keywords: Corporate Social Responsibility, Compensation Management, Performance of The Company.

\section{Introduction}

The development of science and technology which is characterized by increasingly advanced industrial impact on the increasing complexity of operational activities as well as corporate social responsibility. It's resulted in claims against the company are also getting bigger. Good company is not only required to generate a large profit (profit). But also has a concern for the environment (planet) and the welfare of society (people), is due to carry out its operations the company will interact directly or indirectly with the environment.

Indonesian state government are aware of the importance of preserving the environment, issued Law No. 40 of 2007 on Limited Liability Companies, in particular article 74, paragraph 1 which states that companies running business in the field of natural resources and areas related to natural resources required to implement social and environmental responsibility. Although governed by statute but not of necessity, but voluntary CSR. This is because the purpose of the company in running its business in the long term is for profit stakeholders (Dawn, 2010). The company also must pay attention to the costs incurred for CSR and the benefits to be obtained. If the benefits outweigh the costs of social enterprise to disclose information,

Corporate social responsibility basically departs from the philosophy of how to manage the company in part or as a whole has a positive impact for themselves and the environment. To that end, the company should be able to manage business operations by delivering products that positively oriented towards society and the environment.

* Corresponding author. Email address: yosafatgea.y@ gmail.com 
Purnaningsih Corporate Social Responsibility is one form of sustainability reporting which provides information about the various aspects of the company from the aspect economic, environmental, labor, human rights, social, and product responsibility.

Corporate social responsibility can have a positive impact for the company, where the company's CSR activities can enhance public trust so that the company's products also increased the company's reputation in the eyes of society. So people will want to buy the company's products. More and sell the company's products in the market, the profit (profit) that can be produced by the company will increase. With the increase in profit will be able to attract investors, because the profitability is an important consideration for investors in their investment decisions. This will significantly affect its financial performance.

After recognizing the usefulness of social responsibility disclosure will then deciding disclose social information, the company will consider the costs and benefits to be obtained. If the benefits outweigh the costs to disclose social information of the company, the company will voluntarily disclose such information. But not if it costs the company to disclose CSR is greater than the benefit gained (Anggraini, 2006).

To carry out corporate social responsibility, the company would not incur additional costs which are few in number, but the additional cost this shows the magnitude of the company's commitment to undertake social responsibilities. According Kamaludin (2010), the additional costs incurred by the company as a form of social responsibility does not lead to the exchange of negative and will continue to show good performance. The CSR activities are carried out continuously and in the long run it will help the company in reducing various costs, such as promotion and advertising expenses, the costs of hiring and replacement costs due to conflicts that have arisen, so that CSR activities can help companies reduce costs and improve the profitability of the company (Kamaludin, 2010).

Besides the importance of Corporate Social Responsibility, the management company also has a responsibility to manage investors' funds that provide benefits to them and to seek funding from other investors to develop the business. The company makes an accountability report on each year as a reflection of the year's performance of the company to investors. The annual report also serves as a tool to attract investors in order to invest in the company. In the report there are reports of the company's financial performance. Financial performance report is an overview of the financial condition of a company at a certain period. Financial performance assessment can be done through the analysis of ratios that among them there profabilitas ratio analysis.

Profitability is kemempuan companies in the search for profits. Profitability ratio also provides a measure of the effectiveness of management of a company. This is demonstrated by the profit generated from sales and investment income. The point is that the use of this ratio shows the effectiveness of the company, the higher the profit generated then the company is more effective. Profitability ratio can be measured by several indicators, one of which uses indicators Return on Assets (ROA).

Implementation of CSR affect the company's financial performance, it is in accordance with the statement of Robinson and Pearce (2005) in Gantino (2016) that the implementation of CSR create savings so as to increase profits. Profit is one measure of financial performance. According Sugiyono (2012) in Gantino (2016), the financial performance is the end result of the accounting activities (accounting cycle). Arif, et al (2008) in Gantino (2016) stated that the financial statements reflect the financial condition and results of operations.

CSR is run by the management (agent) as the participation of the mandate given by shareholders (principals). To carry out the tasks given by the shareholders, the shareholders provide compensation to management in order for them to work harder. Shareholders gave a mandate to management to act on behalf of shareholders. Management is a party entrusted by shareholders to run the company. Management is obliged to account for what has been mandated by shareholders him. Management 
should carry out obligations optimistic, and then given a special incentive or reward satisfactory from shareholders to management.

If the CEO or executive managers tend to do a CSR activity will increase repurtasi themselves as good citizens and become their personal gain. Good repurtasi will improve management careers both within the company and outside. This would make it more valuable managers and their bargaining power will be higher. The shareholders would pay a manager who has a good repurtasi with high compensation. It dimaksdkan for an agent or shareholders do not lose a director of the company (of Management).

Agency theory states CSR engagement as principal-agent relationship or the relationship between managers and shareholders. Agency theory emphasizes shareholder wealth maximization.Agency theory proposes that when a company follows the structure of separating ownership from control, where the company shareholders delegate to rent control professionals such as CEOs and executives to manage the company on their behalf, there should be no conflict of interest between owners and their agents or their executive (Anderson et al., 2007; Badertscher et al., 2013; Berle and Means, 1968; Foss and Stea, 2014; Hansmann and Kraakman, 2004; Puffer and Weintrop, 1991) in Buachoom (2017).

The contract is the mechanism for granting incentive compensation to align the interests of executives and shareholders. The executives clearly compensated for their benefits based on their efforts to improve the performance of the company, so the compensation should motivate executives to improve the company's performance or maximize shareholder value (Anderson and Bizjak, 2003; Holmstrom, 1979) in Buachoom (2017). With regard to the system of incentives, conflicts between owners and executives can be reduced through executive compensation contracts, as executive satisfying reward for their efforts to improve the wealth of the owner (Florackis 2008) in Buachoom (2017). Especially when it satisfactory executive benefits,

When the conflict between the owners and their agents to overcome, executives can be identified as the selfish who manage the company according to their own benefit rather than for the benefit of the owner, so the owner is faced with finding a way to ensure that the agents perform their duties in the interests of the owner (Anderson et al ., 2007; Eisenhardt, 1989; Puffer and Weintrop, 1991) in Buachoom (2017), This strategy suggests incentives as a way to ensure that owners can use to motivate executive behavior that must be played to serve the interests of the owner or for maximizing corporate wealth.

Based on research conducted by Suciwati et al. (2016) stated that the disclosure of Corporate Social Responsibility When increasing the rate of return of equity capital will rise, and vice versa, when the disclosure of Corporate Social Responsibility falls, the rate of return on own capital will also decrease. Research of Heryanto and Juliarto (2017) states that the accountability activities of the company will influence what will be produced by the company.

Research Parengkuan (2017) stated that Corporate Social Responsibility (CSR) has no effect on ROA (Return on Assets). Selcuk and Kiymaz (2017) research on Corporate Social Responsibility and Corporate Performance. Its discovery found found a negative relationship between CSR and financial performance, which means that companies disclose more information about CSR initiatives in their annual reports have a lower return on assets.

Research on executive compensation by Buachoom (2017) states that there is significant between executive compensation to the improved performance of the company. Research results stated that the higher compensation is predicted as a motivating factor in the company's executives to do a good performance in the next year.

Sigler (2011) examined the relationship between executive compensation and firm performance. Results of research found that there is a positive and significant relationship between executive compensation and company performance measured by 
ROE on an accounting basis. To get the expertise of the company's managers to pay higher.

Kurawa and Saidu (2014) investigated the influence of executive compensation on the financial performance of banks Nigeria causal research design. The results of his research found a positive and significant relationship between executive compensation and profit before tax of sample bank (the main explanatory variable).

Kuo, Li \& Yu (2013) focus on share-based payments to the CEO and the impact on company performance. The study found that the share-based salary increases have beneficial effects on the company's performance.

Research Kazan (2016). Studies conducts research on CEO compensation and the impact on company performance for listed companies in the Nordic countries. The results showed that there was a significant negative correlation between total no compensation for the CEO and the company's performance.

Ozkan (2011) found no significant relationship between the total compensation for the CEO and the company's performance. These findings indicate that nonexecutive directors do not seem to provide monitoring in determining CEO compensation.

Matolcsy et al. (2012) have done more research on CEO compensation structure changes and their consequences on the performance of the company for Australian companies. They make a distinction between companies that change from cash-based compensation structure into an equity and a company that only uses cash-based structure. The results showed that a change in CEO compensation structure is negatively related to firm performance. Based on the background described above, the authors are interested in doing research on "The Effect of Corporate Social Responsibility (CSR) and Compensation Management Performance Against Manufacturing Companies Listed in Indonesia Stock Exchange Year 2014 to 2018"

Based on the data that has been analyzed is found that corporate social responsibility significant positive effect on the performance of Integration and management compensation is not significant positive effect on company performance. This suggests that the development of the Islamic capital market information asymmetry and abnormal returns are also lower so the efficiency of the capital market has also increased.

Furthermore, the explanation in this article will be divided into three parts, the first is a literature review that will explain any theory used in this study and previous research that referenced researcher. The second part is the results and discussion will explain the results of research and discussion of results have been found. Then, the third part is the conclusion that a more concise outline of the research study.

\section{Literature Review and Research Hypotheses Agency Theory}

Agency theory relating to the relationship between the management company (agent) with shareholders (principal). According Moeljono (2005) in Gantino (2016), agency theory is a theory that emphasizes the importance of the owner of the company (principles) in handing the management of the company to the professionals (agents) who understand and understand how to run a business. The emergence of the relationship between agent and principal (agency problems) occurs when managers do not always act in accordance with the interests of shareholders (Ni Nyoman, 2011) in Gantino (2016).

\section{Stakeholder Theory}

Stakeholder theory said that the company not only operating entity for its own sake. But also must provide benefits to the relevant stakeholders, namely shareholders, creditors, customers, suppliers, governments, communities and other parties. The existence of stakeholder groups into consideration for the management company to 
disclose or not any information in the report of the company (Ulum et al., 2008) in Widarjo (2011).

\section{Corporate Social Responsibility}

Corporate social responsibility (CSR) is the commitment of the company or the business world to contribute to the sustainable economic development with attention to corporate social responsibility and focuses on the balance between attention to aspects of economic, social, and environmental. A concept whereby companies integrate social and environmental issues in its interaction with stakeholders voluntarily.

\section{Compensation Management}

Compensation system in the organization must be linked with the objectives and strategy of the organization but also demanding compensation balance between benefits and costs employers with the expectations of the employees. The compensation fee should be at a level that ensures the effectiveness of the company as well as the provision of proper remuneration for all employees to abilities, skills, knowledge and achievement of their performance.

\section{Company performance}

Performance is defined in the Big Indonesian Dictionary (1997) as a noun (noun) means something that is achievable, and demonstrated achievement or ability to work. While the performance is based on the Dictionary of Business and Management is achieved tangible results and can be used to show the positive results achieved. Parameters that are often used to assess the performance of a company is done by using the approach of the financial information taken from the financial statements or other financial statements from the aspects of finance by using financial ratios that can provide guidance and other financial information (Mulyadi, 2001) in Widamunti (2010).

\section{Influence of Corporate Social Responsibility Corporate Performance Against}

Corporate Social Responsibility (CSR) is a concept that an organization, in particular the company has a responsibility to its stakeholders, namely customers, employees, shareholders, communities and the environment in all aspects of company operations.

CSR will affect the company's performance (Indrawan \& Mutmainah, 2011). According Wahyuningsih (2012) in Indrawan and Mutmainah (2011) the company's performance can be measured by financial ratios, such as ROA, ROE, sales growth and other ratios. According to Indrawan and Mutmainah (2011) the disclosure of the expanded will provide a positive signal to the parties interested in the company (stakeholders) as well as the company's shareholders (shareholder). The more extensive the information presented to stakeholders and shareholders will increasingly augment the information received about the company. This will cause the trust to the company's stakeholders and shareholders. This causes the CSR activities undertaken by the company will have an impact on the performance of the company. follows:

Based on the description above, it can be formulated hypothesis of the study as

H1 : Suspected Influential Against Corporate Social Responsibility Corporate Performance.

\section{Compensation Effect Against Corporate Performance Management}

Masson (1971) and Hanlon et al., (2003) in Buachoom (2017) states that the executive compensation package based on performance RET provides a good incentive to improve the future performance of the company. Sun et al., (2009) in Buachoom (2017) supports this view that the stock options granted to company executives is positively related to the performance of the company in the future is measured by 
operating income. Additionally, Abowd (1990) in Buachoom (2017) documented that cash compensation, primarily in the form of bonuses, linked to increased market-based corporate performance in the next year. Jensen and Murphy (1990) in Buachoom (2017) supports that change the company's performance as measured by the share price in accordance with the increase in salaries and executive bonuses.

Thus, we can conclude that when executives are satisfied with their compensation, they usually perform their duties based on good decision making to improve the performance of companies that produce the improvement of their rewards in the future. Direction of the relationship between executive compensation and corporate performance results in the following hypothesis:

H2 : Suspected Compensation Effect Against Corporate Performance Management.

\section{Methods}

The population in this study are all companies listed on the Stock Exchange in 2014-2018. The basis for determining the sample in this research is purposive sampling.Based on the criteria established, acquired 21 companies of 153 manufacturing companies that meet the criteria of the sample with 5-year study period.

The data used in this research is quantitative data is data that is expressed in the figures. The source of data on research ni is of secondary data that have been published by the Indonesia Stock Exchange in the form of the company's annual financial statement data for the period 2014 to 2018 were taken through the Indonesia Stock Exchange website (www.idx.co.id).

\section{Operational Definition and Measurement of Variables \\ Independent variables \\ Corporate Social Responsibility}

Measurement Corporate Social Responsibility (CSR) is to evaluate each of the items disclosed in the company's annual report and sustainability report. Rated 1 if disclosed and rated 0 if it is not disclosed. Then the value of each item is summed to obtain the value of their overall CSR of a company. Broad Index calculation formula Penungkapan CSR (CSRI) as follows:

\section{Compensation Management}

$$
\mathrm{CSRIj}=\frac{\sum X i j}{n} \times 100 \%
$$

This study uses a component of total compensation received by executives of companies in the form of base salary is the salary received by executives and variable salary in the form of an annual bonus, long term incentives, additional income and stock options disclosed in the nominal amount of the company's annual financial statements. The formula to calculate Management Compensation formulated as follows (Widamunti, 2010):

$$
\text { COMPit } \times=\frac{\text { Total Kompensasi Direksi dan Komisaris (Eksekutif) }}{\text { Jumlah anggota Direksi dan Komisaris }}
$$

\section{Dependent Variables \\ Company performance}

A company's performance is a performance that has been achieved by the company in a given period and contained in the financial statements of the company concerned. Daft (2002) in Indrawan and Mutmainah (2011) suggests that the performance is the ability of an organization to achieve its objectives through the effective use of resources and efficient. The company's performance can be measured using profitability ratios of ROA. ROA is known, used by companies to assess the efficiency of its assets in operating activities to generate keuantungan. Return on Assets (ROA) can be formulated as follows (Horne and Wachhowicz, 1997) in Indrawan and Mutmainah (2011): 


$$
R O A=\frac{\text { Net Profit after Tax }}{\text { Total assets }} \times 100 \%
$$

\section{Results and Discussion}

\section{Descriptive Statistics Analysis}

A description of the variables of this study are presented in Table descriptive statistics which show the minimum, maximum, mean, and stansar deviation that can be seen in this table.

Table 1 Descriptive Statistics Test Results

\begin{tabular}{lccccc}
\hline \multicolumn{1}{c}{ Variables } & N & Minimum & Maximum & Mean & Std. deviation \\
\hline Corporate Social Responsibility & 105 & $4: 40$ & 56.04 & 20.6907 & 10.28318 \\
compensation Management & 105 & $1: 33$ & $4: 49$ & 2.9866 & .64063 \\
Company performance & 105 & -22.23 & $18: 26$ & 3.2320 & 7.80021 \\
\hline
\end{tabular}

Source: Data processing (2019)

\section{Classical Assumption Test Results \\ Normality Test Results}

The test results normality of the data in this study can be seen in Table 2 below.

Table 2 Results One Sample Kolmogorov-Smirnov

\begin{tabular}{llc}
\hline & & $\begin{array}{c}\text { Residual } \\
\text { Unstandardized }\end{array}$ \\
\hline $\mathrm{N}$ & & 105 \\
Normal & mean & .0000000 \\
Parameters & Std. deviation & 7.31137467 \\
$\mathrm{a}, \mathrm{b}$ & & .086 \\
Most & Absolute & .047 \\
Extreme & positive & -.086 \\
Differences negative & .086 \\
Test Statistic & $.054 \mathrm{c}$ \\
Asymp. Sig. (2-tailed) & \\
\hline a. Test distribution is Normal. & \\
b. Calculated from data. & \\
Significance Lilliefors Correction. \\
\hline
\end{tabular}

$$
\text { Source: Data processing (2019) }
$$

According to the table 2 values Kolmogorov-Smirnov test statistic obtained significance value of $0.054>0.05$. Thus, it means that the regression model to meet the assumptions of normality.

\section{Test Multicollinearity}

The test results multicollinearity in this study are presented in Table 3 below.

\begin{tabular}{|c|c|c|c|}
\hline & \multirow{2}{*}{ Model } & \multicolumn{2}{|c|}{ Collinearity Statistics } \\
\hline & & Tolerance & VIF \\
\hline \multirow{3}{*}{1} & (Constant) & & \\
\hline & Corporate Social & .916 & 1,092 \\
\hline & $\begin{array}{l}\text { compensation } \\
\text { Management }\end{array}$ & .916 & 1,092 \\
\hline
\end{tabular}

Table 3 Test Results Multicollinearity

Source: Data processing (2019) 
From Table 3 is the variance inflation factor (VIF) all independent variables $<10$ and tolerance> 0.10 . It has been suggested that the regression model is free from multicollinearity.

\section{Autocorrelation Test}

The test results autocorrelation in this study are presented in Table 4 below.

Table 4 Autocorrelation Test Results

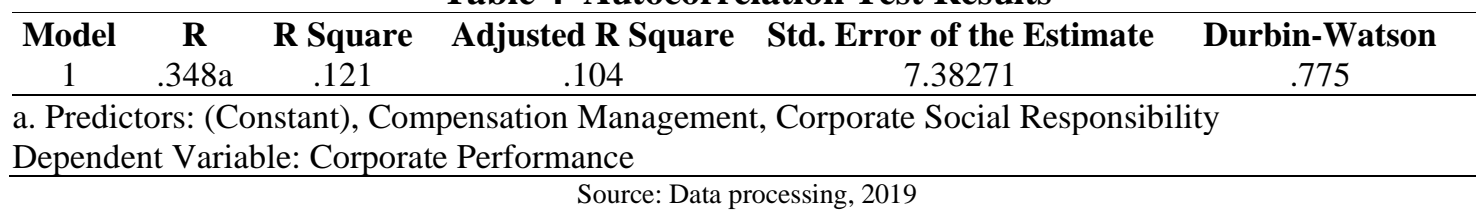

Obtained from tests performed Durbin Watson value of 0.775 which lies between -2 and $+2=-2<0.775<+2$. Thus it can be interpreted that there is no autocorrelation in the regression model.

\section{Heteroscedasticity Test}

The test results heteroskedastisity in this study are presented in Table 5 below.

Table 5 Test Results Heteroskidastity

\begin{tabular}{|c|c|c|c|c|c|}
\hline \multirow[t]{2}{*}{ Model } & \multicolumn{2}{|c|}{$\begin{array}{c}\text { Coefficients } \\
\text { unstandardized }\end{array}$} & \multirow{2}{*}{$\begin{array}{c}\text { standardized } \\
\text { Coefficients } \\
\text { beta } \\
\end{array}$} & \multirow[t]{2}{*}{$\mathbf{t}$} & \multirow[t]{2}{*}{ Sig. } \\
\hline & B & Std. Error & & & \\
\hline 1 (Constant) & 2,172 & 1,058 & & 2,054 & .043 \\
\hline Corporate Social Responsibility & -.037 & .022 & -.168 & -1653 & .101 \\
\hline compensation Management & .381 & .358 & .108 & 1,063 & .290 \\
\hline Dependent Variable: Lnei2 & & & & & \\
\hline
\end{tabular}

From the above test Park is known that the independent variable is not significant to Lnei2 (0.101 and 0.290> 0.05). It has been suggested that there is no regression model heterokedastisitas in this study.

\section{Test Results The coefficient of determination (R2 Test)}

Test Results The coefficient of determination can be seen in table 6 below.

Table 6 Coefficient Determination Test Results

\begin{tabular}{|c|c|c|c|c|c|}
\hline Model & $\mathbf{R}$ & R Square & Adjusted R Square & Std. Error of the Estimate & Durbin-Watson \\
\hline 1 & $.348 \mathrm{a}$ & .121 & .104 & 7.38271 & .775 \\
\hline \multicolumn{6}{|c|}{$\begin{array}{l}\text { a. Predictors: (Constant), Compensation Management, Corporate Social Responsibility } \\
\text { Dependent Variable: Corporate Performance }\end{array}$} \\
\hline
\end{tabular}

$$
\text { Source: Data processing (2019) }
$$

Based on the results uj coefficient of determination in Table 6 above, the value of determination coefficient of 0.121 . What this means is that the percentage of CSR and compensation management influence on the performance of the company is $12.1 \%$. While the remaining $87.9 \%$ is influenced by other variables not included in this regression model.

\section{Simultaneous Effect Test (F Test)}

Test Results simultaneous effect can be seen in table 7 below. 
Effect of Corporate Social Responsibility (CSR) and Compensation For Performance Management

Manufacturing Companies Listed in Indonesia Stock Exchange Year 2014-2018

Table 7 Results of Regression Coefficients Simultaneous Test (Test F)

\begin{tabular}{llcccc}
\hline \multicolumn{1}{c}{ Model } & $\begin{array}{c}\text { Sum of } \\
\text { Squares }\end{array}$ & df & $\begin{array}{c}\text { mean } \\
\text { Square }\end{array}$ & F & Sig. \\
\hline 1 Regression & 768257 & 2 & 384128 & 7048 & $.001 \mathrm{~b}$ \\
residual & 5559.445 & 102 & 54504 & & \\
\multicolumn{7}{l}{ Total } & 6327.702 & 104 & & & \\
\hline a. Dependent Variable: Corporate Performance & & \\
b. Predictors: (Constant), Compensation Management, Corporate Social Responsibility \\
\hline
\end{tabular}

Source: Data processing (2019)

From the table above F count F test (7.048)> F table (3.085) with Sig. (0.001) $<0.05$. What this means is that CSR and management compensation jointly affect the performance of the company.

\section{Partial Test (t test)}

Test Results simultaneous effect can be seen in Table 8 below.

Table 8 Test Results Partial Regression Coefficients (TEST t)

\begin{tabular}{|c|c|c|c|c|c|}
\hline \multirow[t]{2}{*}{ Model } & \multicolumn{2}{|c|}{$\begin{array}{c}\text { Coefficients } \\
\text { unstandardized }\end{array}$} & \multirow{2}{*}{$\begin{array}{c}\begin{array}{c}\text { Standardized } \\
\text { Coefficients }\end{array} \\
\text { beta } \\
\end{array}$} & \multirow[t]{2}{*}{$\mathbf{t}$} & \multirow[t]{2}{*}{ Sig. } \\
\hline & $\mathbf{B}$ & Std. Error & & & \\
\hline 1 (Constant) & -3359 & 3487 & & -.963 & .338 \\
\hline Corporate Social Responsibility & .255 & .074 & .336 & 3467 & .001 \\
\hline compensation Management & .440 & 1,181 & .036 & .372 & .710 \\
\hline
\end{tabular}

Source: Data processing (2019)

\section{Discussion}

Influence of Corporate Social Responsibility to Corporate Performance

Known $t$ arithmetic $(3.467)>t$ table $(1,983)$ or Sig. $(0.001)<0.05$. This means that CSR affects the performance of the company.

\section{Compensation Effect on Corporate Performance Management}

Known $t$ arithmetic $(0.372)<t$ table $(1,983)$ or Sig. $(0.710)>0.05$. This means that managerial compensation does not affect the performance of the company.

\section{Conclusion}

Based on the results of research and discussion in the previous chapter, it can be concluded:

1. Corporate social responsibility significant positive effect on the company's performance.

2. Compensation management does not affect the performance of the company.

\section{References}

Anggraini, F. R. R. (2006). Disclosure of Social Information and Factors Affecting Social Information Disclosure in Annual Financial Statements (Empirical Study on Enterprises listed in Jakarta Stock Exchange. The National Symposium Akuntansi 9 Padang.

Buachoom, W. (2017). Simultaneous Relationship Between Performance And Executive Compensation Of Thai Non-Financial Firms. Asian Review of Accounting, 25(3), 404-423. 
Dawn, M. F. N. (2010). Corporate Social Responsibility in Indonesia: A study of the application of the CSR on multi-national companies, national private and state-owned companies in Indonesia. [Dissertation]. Yogyakarta: Universitas Muhammadiyah Yogyakarta.

Gantino, R. (2016). Influence of Corporate Social Responsibility Financial Performance Against Manufacturing Companies Listed in Indonesia Stock Exchange Period 2008-2014. Journal dynamics and Accounting and Business, 3(2), 18-31.

Heryanto, R., \& Juliarto, A. (2017). Influence of Corporate Social Responsibility Against the profitability of the Company. Diponegoro Journal of Accounting, 6(4), 1-8.

Indrawan, D. C., \& Mutmainah, S. (2011). Influence of Corporate Social Responsibility of the Company's performance. [Thesis]. Semarang: Universitas Diponegoro.

Kamaludin. (2010). Influence of Corporate Social Responsibility Disclosure on Profitability and Corporate Reputation (Empirical Study on Companies Listed in Indonesia Stock Exchange). [Skripsi]. Jakarta: Universitas Islam Negeri Syarif Hidayatullah.

Kazan, E. (2016). The impact of CEO compensation on firm performance in Scandinavia. Netherland: University of Twente.

Kuo, C. S., M. Y. L. Li., \& Yu, S. E. (2013). Non-uniform effects of CEO equity-based compensation on firm performance - An application of the panel threshold regression models. The British Accounting Review, 45(3), 203-214.

Kurawa, J. M., \& Kabiru, S. (2014). Executive Compensation And Financial Performance Of Listed Banks In Nigeria: An Empirical Analysis. Researchjournali's Journal of Accounting, 2(3).

Matolcsy, Z., Shan, Y., \& Seethamraju, V. (2012). The timing of changes in CEO compensation form of cash bonuses to equity-based compensation: Determinants and Consequences performance. Journal of Contemporary Accounting \& Economics, 8(2), 78-91.

Ozkan, N. (2011). CEO Compensation and Firm Performance: an Empirical Investigation of the UK Panel Data. The European Financial Management, 17(2), 260-285.

Parengkuan, W. E. (2017). The Influence of Corporate Social Responsibility (CSR) to Manufacture Financial Performance That Listed in Indonesian Stock Exchange Through Stock Corner of Faculty of Economy and Business UNSRAT. Journal EMBA, 5(2), 564-571.

Selcuk, E. A., \& Kiymaz, H. (2017). Corporate Social Responsibility and Firm Performance: Evidence from an Emerging Market. Accounting and Finance Research, 6(4).

Sigler, K. J. (2011). CEO Compensation and Company Performance. Business and Economics Journal. 
Suciwati, D. P., Pradnyan, D. P. A., \& Ardina, C. (2016). Influence of Corporate Social Responsibility Toward Financial Performance (On Mining Sector Companies In Bei Years 2010-2013). Journal of Business and Entrepreneurship, 12(2).

Widamunti, Y. (2010). Executive Management Compensation Effect Analysis of Performance Against Companies With Dividend Policy As an intervening variable. [Skripsi]. Surakarta: Universitas Negeri Sebelas Maret.

Widarjo, W. (2011). The effect of the intellectual capital and Intellectual Capital Disclosures On Value Company Conducting an Initial Public Offering. Journal of Accounting and Finance Indonesia, 8(2), 157-170. 